\title{
Phytase-Producing Bacteria from Extreme Regions in Indonesia
}

\author{
Sajidan $^{1}$, Rita Wulandari ${ }^{2}$, Evy Novita Sari ${ }^{2}$, Adi Ratriyanto ${ }^{3}$, Hailu Weldekiros ${ }^{4}$ and Ralf \\ Greiner $^{5^{*}}$ \\ ${ }^{I}$ Department of Biology Education; Sebalas Maret University; Jalan Ir, Solo - Indonesia. ${ }^{2}$ Bioscience Program; Sebalas \\ Maret University; Jalan Ir. Sutami, Solo - Indonesia. ${ }^{3}$ Faculty of Agriculture; Sebalas Maret University; Jalan Ir. Sutami, \\ Solo - Indonesia. ${ }^{4}$ Bahir Dar University; Bahir Dar, Amhara - Ethiopia. ${ }^{5}$ Department of Food Technology and Bioprocess \\ Engineering; Max Rubner-Institut; Federal Research Institute of Nutrition and Food; Haid-und-Neu-Straße 9, Karlsruhe - \\ Germany
}

\begin{abstract}
In this study, 154 isolates capable of producing extracellular phytate-degrading activity were isolated from four soil samples from volcanic areas in Central Java, Indonesia. Six strains with high phytate-degrading activity were selected for strain identification and characterization of the corresponding phytate-degrading enzyme. Blast analysis of $16 \mathrm{~S}$ rRNA gene sequences revealed high similarities for all the six isolates to reference sequences belonging to the genus Bacillus. Isolates MS5, MC6, D10 and D16 showed $99 \%$ sequence identity to B. cereus, while isolate MC8 exhibited 99\% sequence identity to B. aryabhatti and D6 99\% sequence identity to B. psychrotolerans. The crude extracellular phytase preparations from the isolates showed following optimal conditions for phytate dephosphorylation: $\mathrm{pH} 4.0$ and $50^{\circ} \mathrm{C}$ (isolate D10), $\mathrm{pH} 5.0$ and $60^{\circ} \mathrm{C}$ (isolate $\mathrm{MC6}$, and isolate MS5), $\mathrm{pH} 6.0$ and $50^{\circ} \mathrm{C}$ (isolate D16) and $\mathrm{pH} 6.0$ and $60^{\circ} \mathrm{C}$ (isolate D6) and $\mathrm{pH} 6.0$ and $40^{\circ} \mathrm{C}$ (isolate MC8). $\mathrm{Zn}^{2+}$ and $\mathrm{Fe}^{3+}$ strongly inhibited phytate dephosphorylation with all phytase preparations studied. In the presence of $\mathrm{Ca}^{2+}$, an increase in phytase activity of 10-15\% was obtained.
\end{abstract}

Key words: 16S rDNA, Bacillus sp.; bacterial phytase; phytate; phytate-degrading enzyme

\section{INTRODUCTION}

Phytate [myo-inositol $\quad(1,2,3,4,5,6)$ hexakisphosphate] is the major storage form of phosphate in plant seeds and grains (Konietzny and Greiner 2002). Therefore, phosphate is predominately organically bound in plant-based food and feed. It was reported that about $30 \%$ of the phosphate present in plant-based feed exist in its free form and the remaining $70 \%$ in form of phytate (Kembhavi 2005). Due to is high negative charge under physiological conditions, phytate forms strong complexes with cations such as proteins, amino acids, minerals and trace elements, and thus renders them less available for absorption (Weaver and Kannan 2001). In addition, monogaster are not capable of dephosphorylating phytate during the digestion due to the lack of significant amounts of endogenous phytatedegrading activity in their stomach and small intestine (Iqbal et al. 1994). To ensure the optimal growth of animals such as pigs and poultry, animal feed must be supplemented with inorganic phosphate. However, rock phosphate is a nonrenewable natural resource and it might become scarce in the near future (Abelson 1999; Ashley et al. 2011). Furthermore, the phytate reaching the large intestine of monogaster is either

\footnotetext{
*Author for correspondence: ralf.greiner@mri.bund.de
} 
dephosphorylated by the intestinal microflora or excreted via the feces and dephosphorylated by soil and water microorganisms. Therefore, high amounts of phosphate are released into the environment in the areas of intense life-stock management. The resulting pollution of ground and surface waters causes algae blooming, a decrease in oxygen levels, and death of aquatic animals (Shin et al. 2001).

Phytases are enzymes catalyzing the stepwise release of phosphate residues from the myoinositol ring of phytate (Jorquera et al. 2008). These enzymes are ubiquitous in nature and have been reported from more than 2000 microbial soil isolates. Phytases are a diverse group of enzymes that encompass a range of sizes, structures and catalytic mechanisms. Based on the catalytic mechanism, phytases can be referred to as histidine acid phytases, $\beta$--propeller phytases, cysteine phytases or purple acid phytases (Greiner and Konietzny 2006). Depending on their $\mathrm{pH}$ optimum, phytases have been divided into acid and alkaline phytases, and based on the carbon in the myo-inositol ring of phytate at which dephosphorylation is initiated into 3-phytases (E.C. 3.1.3.8), 6-phytases (E.C. 3.1.3.26) and 5phytases (E.C. 3.1.3.72).

Phytases were originally proposed as an animal feed additive to enhance the value of plant material in animal feed by liberating phosphate (Mitchell et al. 1997). Phytase is present in about $75 \%$ of all the diets for simple-stomach animals and its market volume exceeds US\$350 million annually (Shivange et al. 2012). The current global phytase market has been estimated to account for more than $60 \%$ of the total enzyme market. The increase in economic pressure and increased concern over the environmental impact of lifestock production, have paved the way for the economic success of phytases as an animal feed additive. Phytases used for animal feed application differ in their enzymatic properties such as $\mathrm{pH}$ profile, stability under stomach conditions, temperature stability, kinetic constants, and substrate specificity. 'Ideal' phytases for animal feed applications should fulfil a series of quality criteria. They should be effective in releasing phytate phosphate in the digestive tract, stable to resist inactivation by heat during the feed processing and storage as well as cheap to produce.

Thermal stability is a particularly important issue since feed pelleting is commonly performed at temperatures between 60 and $95^{\circ} \mathrm{C}$. Although phytase inclusion using an after-spray apparatus for pelleted diets and/or chemical coating of phytase may help bypass or overcome the heat destruction of the enzyme, thermostable phytases would no doubt be better candidates for feed supplements. Thus, the aim of the study was to isolate phytase-producing bacteria from volcanic areas in Central Java, Indonesia.

\section{MATERIAL AND METHODS}

\section{Soil sampling}

Four days after eruption, two samples of volcanic ash were taken from Selo on the north side of Mount Merapi in Central Java, Indonesia, and from Cangkringan Yogyakarta on the south side of the mountain. Two samples of mud and water were taken from Sikidang crater on Dieng Mountain, also in Central Java. During the collection, the temperature of the samples was $60^{\circ} \mathrm{C}$.

\section{Isolation of phytate-degrading bacteria}

One gram of sample was suspended in $10 \mathrm{~mL}$ of $1 \%$ sodium chloride solution. The suspensions were diluted $10^{2}$ to $10^{6}$ fold and each dilution (10 $\mu \mathrm{L})$ was plated onto $\mathrm{LB}$ plates containing $\left(\mathrm{g} \mathrm{L}^{-1}\right)$ 10 tryptone, 5.0 yeast extract, $10 \mathrm{NaCl}$, and 15 agar for the isolation of phytate-degrading bacteria. The $\mathrm{pH}$ value of the media was adjusted to $\mathrm{pH}$ 7.0. Petri dishes were incubated at $37^{\circ} \mathrm{C}$ for 16 hours. Thereafter, single colonies were grown in liquid LB supplemented with Na-phytate $\left(4 \mathrm{~g} \mathrm{~L}^{-1}\right)$ at $37^{\circ} \mathrm{C}$ for $16 \mathrm{~h}$. After pelleting the bacteria cells by centrifugation at $3,500 g$ for 5 min, phytase activity was determined in the supernatants.

\section{Standard phytase activity assay}

The spectrophotometric assay was carried out in a total volume of $150 \mu \mathrm{L}$ at $37^{\circ} \mathrm{C}$ for $60 \mathrm{~min}$. The reaction mixture consisted of $125 \mu \mathrm{L} 0.1 \mathrm{M}$ sodium acetate buffer ( $\mathrm{pH} 5.0$ ) containing $5 \mathrm{mM}$ sodium phytate and $25 \mu \mathrm{L}$ of the enzyme preparation. The liberated $P_{i}$ was measured using a modified ammonium molybdate method (Heinonen and Lahti 1981). The reaction was terminated by the addition of $750 \mu \mathrm{L}$ of a freshly prepared solution consisting of acetone, $2.5 \mathrm{M}$ sulfuric acid and $10 \mathrm{mM}$ ammonium molybdate $(2: 1: 1 \mathrm{v} / \mathrm{v})$. Thereafter, $100 \mu \mathrm{L}$ of $1 \mathrm{M}$ of citric acid were added. Absorbance was determined at 
$355 \mathrm{~nm}$. A calibration curve was prepared from 5 to $600 \mathrm{mM}$ phosphate. Phytate-degrading activity (U) was defined as the amount of enzyme that released $1 \mu \mathrm{mol}$ phosphate per min.

To study the $\mathrm{pH}$ optimum of the phytate-degrading enzymes, the following buffers were used in the above described standard phytase activity assay: $\mathrm{pH}$ 3.0-6.0, 0.1 M sodium acetate-acetic acid; $\mathrm{pH}$ 6.07.0, 0.1 M Tris-acetic acid; $\mathrm{pH}$ 7.0-9.0, 0.1 M Tris$\mathrm{HCl}$.

The temperature profiles of the phytate-degrading enzymes were determined in the temperature range from 30 to $90^{\circ} \mathrm{C}$ using the standard phytase activity assay. The effect of cations on enzyme activity was investigated by pre-incubating the compounds with phytate-degrading enzymes for $15 \mathrm{~min}$ at $37^{\circ} \mathrm{C}$ before the standard phytase activity assay was performed. The following cations and potential inhibitors were used in a concentration of $1.0 \mathrm{mM}$ and $0.1 \mathrm{mM}: \mathrm{Mg}^{2+}, \mathrm{Ca}^{2+}, \mathrm{Fe}^{3+}$, and $\mathrm{Zn}^{2+}$.

\section{Identification of phytase producing bacteria}

The bacterial strains were cultured at $37^{\circ} \mathrm{C}$ for $16 \mathrm{~h}$ in LB supplemented with $0.4 \%$ Na-phytate. Then the cells were pelleted by centrifugation at $3,500 \mathrm{~g}$ for $10 \mathrm{~min}$. Extraction of the DNA was performed using the Wizard ${ }^{\circledR}$ Genomic DNA Purification Kit (Promega) according to the instructions of the manufacturer using 5'-GAGAGTTTGATCCTGG CTCAG-3' as a forward and 5'- CTGTTTGCTCCC CACGCTTTC-3' as a reversed primer for the amplification of the 16S rDNA as described by Damiani et al. (1996). The PCR reaction mixtures contained $2.0 \mu \mathrm{L}$ of a dNTPs mixture $(1.25 \mathrm{mM}$ each), $1.0 \mu \mathrm{L}$ of each primer $(20 \mathrm{mM}), 2.5 \mu \mathrm{L}$ of DNA, $1.0 \mu \mathrm{L}$ of Taq polymerase and sterile deionized water to bring the final volume to $100 \mu \mathrm{L}$. The mixtures were denatured at $95^{\circ} \mathrm{C}$ for $4 \mathrm{~min}$. The PCR temperature profile consisted of 30 cycles of $60 \mathrm{~s}$ denaturation at $95^{\circ} \mathrm{C}, 45 \mathrm{~s}$ annealing at $50^{\circ} \mathrm{C}$ and $90 \mathrm{~s}$ primer extension at $72^{\circ} \mathrm{C}$ followed by a final extension at $72^{\circ} \mathrm{C}$ for $10 \mathrm{~min}$. A negative control was included to eliminate the possibility of reagent contamination. PCR products were analysed using agarose $(0.8 \%)$ gel electrophoresis and visualized using ethidium bromide. The identity of the bacteria detected by the 16S rRNA PCR was revealed by sequencing of the PCR products $\left(1^{\text {st }}\right.$ Base Singapore, Singapore) and comparison of these sequences to the Genbank database using the BLAST program available at the National Centre for Biotechnology Information (http://www.ncbi. nlm.nih.gov). Cluster analysis was performed using the Multiple Clustal Alignment software from Clustal W (www.ebi.ac.uk/tool/msa/clustalW).

\section{RESULTS}

\section{Screening for phytate-degrading enzyme producing bacteria}

One hundred thirty four single colonies were obtained from the two soil samples taken from Dieng Mountain (D1-D134) and 10 single colonies, each from the soil samples taken from Selo (MS1-MS10) and Cangkringan Yogyakarta (MC1-MC10). The isolates derived from Merapi Mountain exhibited an extracellular phytatedegrading activity between 77.6 and $107.1 \mathrm{mU}$ $\mathrm{mL}^{-1}$ (Fig. 1).

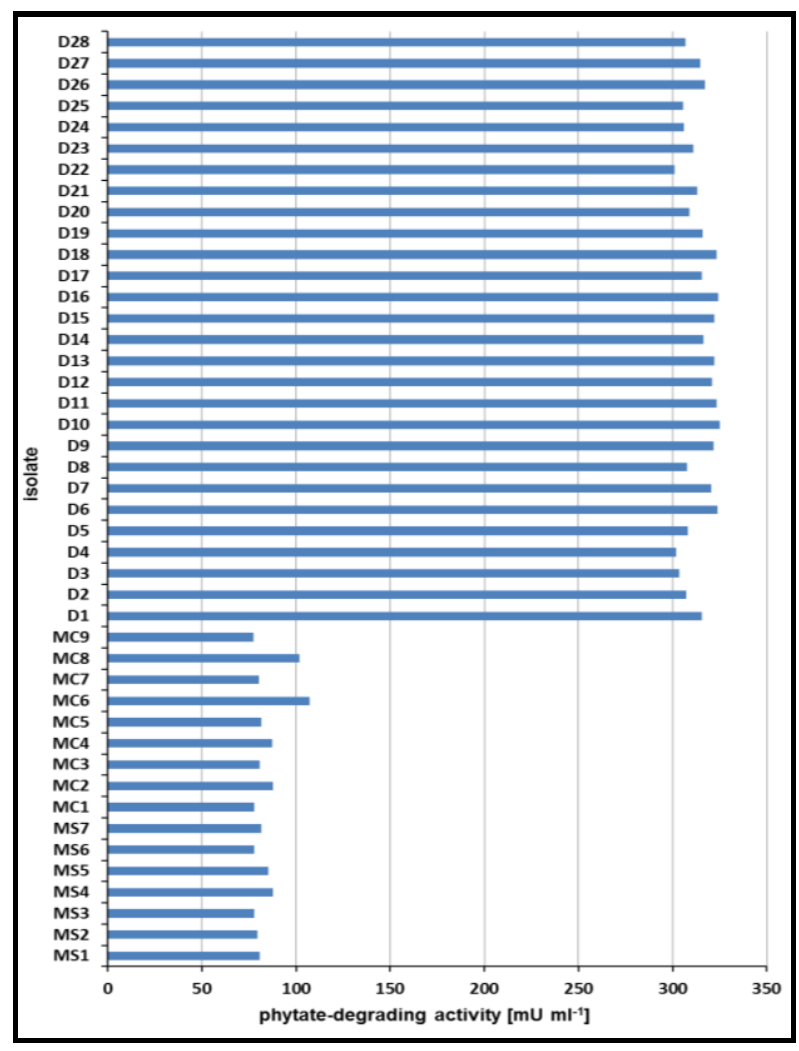

Figure 1 - Extracellular phytate-degrading activity of the positive isolates derived from Merapi Mountain north side (MS), Merapi Mountain south side (MC) and Dieng Mountain (D) after fermentation for $16 \mathrm{hrs}$ at $37^{\circ} \mathrm{C}$ in liquid $\mathrm{LB}$ supplemented with sodium phytate.

No significant difference in the extracellular phytate-degrading activity was observed for the isolates from the Selo (MS1-MS7), or the 
Cangkringan Yogyakarta (MC1-MC9) soil sample. The isolates derived from Dieng Mountain (D1D28), however, showed a significant higher extracellular phytate-degrading activity (300.8 to $323.9 \mathrm{mU} \mathrm{mL}^{-1}$ ) compared to the isolates from Merapi Mountain.

\section{Identification of phytate-degrading enzyme producing bacteria}

Blast analysis of the partial 16S rRNA gene sequences six isolates (MS5, MC6, MC8, D6, D10 and D16) showed high similarities to the reference sequences to the genus Bacillus. Isolates MS5, MC6, D10 and D16 showed 99\% sequence identity to $B$. cereus, while isolate MC8 exhibited $99 \%$ sequence identity to $B$. aryabhatti and D6 $99 \%$ sequence identity to $B$. psychrotolerans.

Neighbor-joining phylogenetic analysis of the sequence data revealed that the all the six isolates were located in three distinct clusters (Fig. 2). Group 1 consisted of the closely related isolates MS5 and MC6 as well as B. cereus, whereas group 2 comprised the isolate D6 and MC8 as well as $B$. aryabhattai. Group 3 consisted of the closely related isolates D10 and D16 as well as two uncultured bacteria clones.

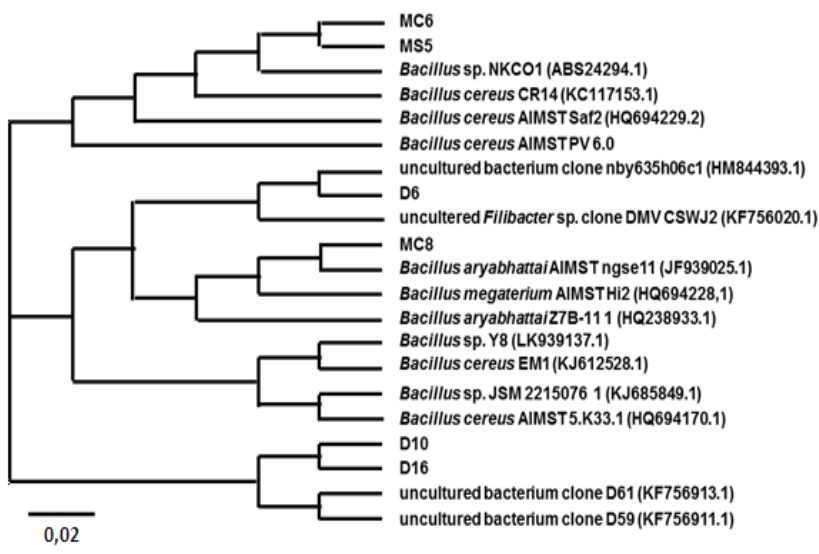

Figure 2 - ClustalW phylogenetic tree based on 16S rRNA multiple sequence alignment of phytase-producing bacteria.

\section{Properties of the phytate-degrading enzymes}

Optimal conditions for phytate dephosphorylation were determined using the crude extracellular phytase preparations from the isolates. The $\mathrm{pH}$ optimum of the phytase preparation of isolate D10 was 4.0, which was 5.0 for the isolates MC6 and MS5 and 6.0 for the isolates D6, D16 and MC8 (Fig. 3). For all the isolates, the $\mathrm{pH}$ profile for phytate dephosphorylation was broad, pointing to the presence for more than one phytate-degrading enzyme in the crude enzyme preparations. Isolate MC 8 showed temperature optima at $40^{\circ} \mathrm{C}$ for its phytase preparation, which was $50^{\circ} \mathrm{C}$ for the phytase preparation from the isolates D10 and D16 and $60^{\circ} \mathrm{C}$ for the isolates D6, MS5 and MC6 (Fig. $4)$.

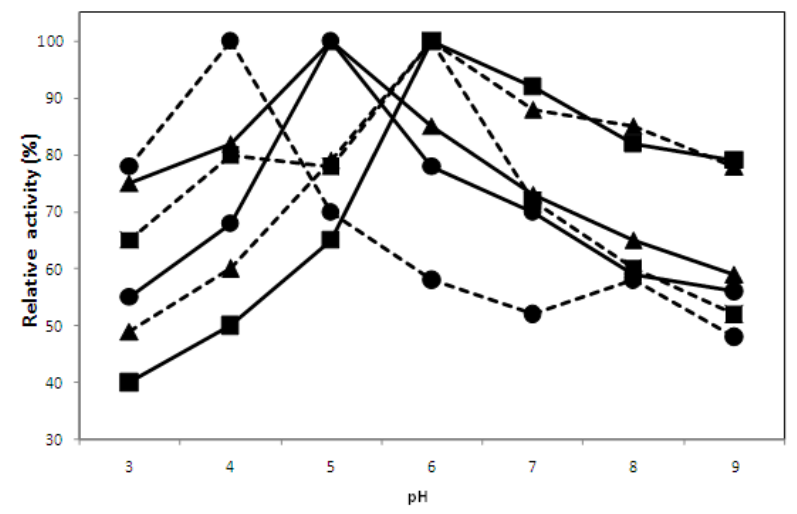

Figure 3 - pH Profile of phytate dephosphorylation by the crude phytase preparations of isolate D6

$$
\begin{aligned}
& (-) \text {, D10 (- ), D16 (- }) \text {, MS5 (-) } \\
& \text { MC6 (누), and MC8 (느). }
\end{aligned}
$$

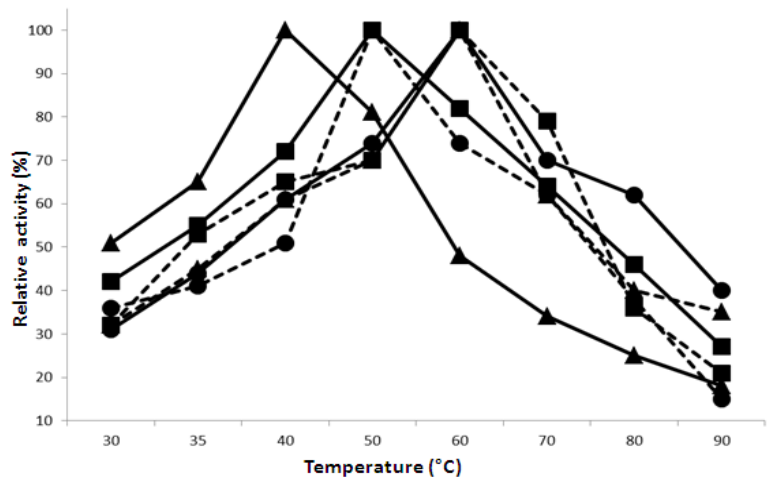

Figure 4 - Temperature profile of phytate dephosphorylation by the crude phytase preparations of isolate D6

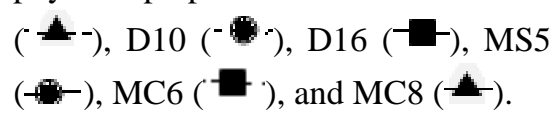

Results on the study of the effect of cations showed that $0.1 \mathrm{mM}$ and $1.0 \mathrm{mM} \mathrm{Mg}{ }^{2+}$ did not affect phytase activity at all. $\mathrm{Zn}^{2+}$ and $\mathrm{Fe}^{3+}$, however, were strong inhibitors of phytate dephosphorylation with all phytase preparations

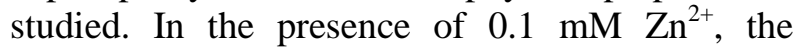
reduction of phytase activity was $12-17 \%$. A $22-$ $28 \%$ reduction was observed in the presence of 1 
$\mathrm{mM} \mathrm{Zn}{ }^{2+}$. A concentration of $0.1 \mathrm{mM} \mathrm{Fe}^{3+}$ resulted in a decrease in phytase activity of $18-24 \%$, whereas a $32-36 \%$ reduction was observed in the presence of $1 \mathrm{mM} \mathrm{Fe}{ }^{3+}$. In the presence of $0.1 \mathrm{mM}$ and $1.0 \mathrm{mM} \mathrm{Ca}^{2+}$ an increase in phytase activity of $10-15 \%$ was determined (Table 1 ).

Table 1 - Effects of potential inhibitors on phytase activity.

\begin{tabular}{|c|c|c|c|c|c|c|c|c|}
\hline \multirow{3}{*}{ phytase isolate } & \multicolumn{8}{|c|}{ residual activity [\%] } \\
\hline & \multicolumn{2}{|c|}{$\mathrm{Mg}^{2+}$} & \multicolumn{2}{|c|}{$\mathrm{Zn}^{2+}$} & \multicolumn{2}{|c|}{$\mathrm{Fe}^{3+}$} & \multicolumn{2}{|c|}{$\mathrm{Ca}^{2+}$} \\
\hline & $0.1 \mathrm{mM}$ & $1.0 \mathrm{mM}$ & $0.1 \mathrm{mM}$ & $1.0 \mathrm{mM}$ & $0.1 \mathrm{mM}$ & $1.0 \mathrm{mM}$ & $0.1 \mathrm{mM}$ & $1.0 \mathrm{mM}$ \\
\hline D6 & no effect & no effect & 84.2 & 73.3 & 78.1 & 65.4 & 114.2 & 114.6 \\
\hline D10 & no effect & no effect & 85.4 & 73.4 & 70.8 & 67.6 & 109.8 & 110.1 \\
\hline D16 & no effect & no effect & 83.7 & 72.8 & 77.6 & 65.2 & 114.4 & 114.9 \\
\hline MS5 & no effect & no effect & 88.3 & 77.9 & 82.1 & 68.4 & 111.3 & 111.4 \\
\hline MC6 & no effect & no effect & 86.7 & 77.1 & 81.3 & 67.1 & 110.7 & 110.9 \\
\hline MC8 & no effect & no effect & 82.9 & 71.7 & 76.3 & 63.9 & 114.7 & 115.3 \\
\hline
\end{tabular}

The data are mean values of three independent experiments.

\section{DISCUSSION}

Bacillus sp. has been identified as the predominant producer of extracellular phytate-degrading activity in the soil samples of different origin (Kerovuo et al. 1998; Kim et al. 1998; Choi et al. 2001; Park 2001; Joseph and Raj 2007; Gulati et al. 2007; Anis Sobirin et al. 2009; Shamna et al. 2012; El-Toukhy et al. 2013; Kumar et al. 2013; Singh et al. 2013; Ushasri et al. 2013; Demirkan et al. 2014; Jain and Chauhan 2014). To our knowledge, B. aryabhattai, however, has been found for the first time as a phytase producer. The ability of the different Bacillus strains investigated to produce extracellular phytate-degrading activity was dependent on the strain itself as well as the culture conditions used. The results obtained in this study (77.6 - $323.9 \mathrm{mU} \mathrm{mL} \mathrm{mL}^{-1}$ ) were in good agreement with those already reported for Bacillus sp. KHU-10 (60 mU mL $\left.\mathrm{mL}^{-1}\right)$ (Choi 2001), B. laevolacticus $\left(158-283 \mathrm{mU} \mathrm{mL}^{-1}\right)$ (Gulati et al 2007) and B. subtilis DR6 (129 - $\left.378 \mathrm{mU} \mathrm{mL}^{-1}\right)$ (Singh et al. 2013). Other studies reported significantly higher extracellular phytase activities such as $720 \mathrm{U} \mathrm{mL}^{-1}$ (B. subtilis MJA) (El-Toukhy et al. 2013), $20-150 \mathrm{U} \mathrm{mL}^{-1}$ (B. subtilis) (Powar and Jagannathan 1982), $55-88 \mathrm{U} \mathrm{mL}^{-1}(B$. subtilis) (Shamna et al. 2012), and $39-348 \mathrm{U} \mathrm{mL}^{-1}$ (B. cereus and B. subtilis) (Anis Sobirin et al. 2009). The differences in phytase production might be explained by the difference in the phytase expression levels among the Bacillus strains studied and in the application of optimised culture conditions in respect to phytase production. Histidine acid phytases, $\beta$--propeller phytases and cysteine phytases have been identified in bacteria (Greiner and Konietzny 2006). The majority of the so far known phytases belong to the subfamily of histidine acid phosphatases and do not need any co-factor for optimal activity. Currently, all the phytases used for the animal feed application belong to the class of histidine acid phytases. Cysteine phytases have been reported from the anaerobic ruminal bacteria (Chu et al. 2004) and these enzymes also do not need any co-factor for enzymatic activity. The amino acid sequences of B-propeller phytases exhibit no homology to the sequences of any other known phosphatase (Kerovuo et al. 1998; Kim et al. 1998; Ha et al. 2000). Initially, B-propeller phytases were reported from Bacillus species (Kerovuo et al. 1998; Kim et al. 1998; Choi et al. 2001; Tye et al. 2002), but protein sequence identity suggested that Bpropeller phytases were widespread in the aquatic environment (Cheng and Lim 2006). In contrast to the other two phytase subfamilies, B-propeller phytases need calcium ions for optimal stability and enzymatic activity (Powar and Jagannathan 1982; Shimizu 1992; Kerovuo et al. 1998; Kim et al. 1998; Choi et al. 2001; Oh et al. 2001; Park 2001; Shin et al. 2001; Gulati et al. 2007; Anis Sobirin et al. 2009; El-Toukhy et al. 2013; Kumar et al. 2013; Yu and Chen 2013; Jain and Chauhan 2014). Maximum phytase activity of B-propeller phytases occurs in the $\mathrm{pH}$ range of 6.5 to 8.0 (Choi et al. 2001; Gulati et al. 2007; Jain and Chauhan 2014; Kerovuo et al. 1998; Kim et al. 1998; Oh et al. 2001; Park 2001; Powar and Jagannathan 1982; Shimizu 1992; Yu and Chen 2013). All the six Bacillus strain included in this study exhibited a broad $\mathrm{pH}$ profile. Interestingly, for three of the strains investigated, a significant higher phytatedegrading activity under acidic compared to neutral conditions was observed. The presence of 
more than one phytate-degrading enzyme in the Bacillus strains might explain this observation. This conclusion was further confirmed by the relatively high temperature optimum at $\mathrm{pH} 5.0$ in the absence of $\mathrm{Ca}^{2+}$. Optimal temperature for phytate dephosphorylationy was at 40,50 and $60^{\circ} \mathrm{C}$. In the absence of calcium ions in the assay buffer, temperature optima around $40^{\circ} \mathrm{C}$ were reported for Bacillus phytases (Powar and Jagannathan 1982; Choi et al. 2001; Park 2001; El Thouky et al. 2013), whereas higher temperature optima $\left(60-70^{\circ} \mathrm{C}\right)$ were found in the presence of 1 - $5 \mathrm{mM} \mathrm{Ca}^{2+}$ (Kerovuo et al. 1998; Kim et al. 1998; Park 2001; Choi et al. 2001, Gulati et al. 2007; Jain and Chauhan 2014). The Bacillus phytases investigated in this study exhibited an increased phytase activity in the presence of $\mathrm{Ca}^{2+}$ and decreased phytase activity in the presence of $\mathrm{Zn}^{2+}$ and $\mathrm{Fe}^{2+} . \mathrm{Mg}^{2+}$ did not show any effect on enzymatic activity. This was in accordance with already reported data on phytases (Konietzny and Greiner 2002).

\section{REFERENCES}

Abelson PH. A potential phosphate crisis. Science 1999; 283: 2015.

Anis Shobirin MH, Farouk A, Greiner R. Potential phytate-degrading enzyme producing bacteria isolated from Malaysian maize plantation. Afr $J$ Biotechnol. 2009; 8: 3540-3546.

Ashle, K, Cordell D, Mavinic D. A brief history of phosphorus: From the philosopher's stone to nutrient recovery and reuse. Chemosphere 2011; 84: 737-746.

Cheng C, Lim BL. Beta-propeller phytases in the aquatic environment. Arch Microbiol. 2006; 185: 113.

Choi YM, Suh HJ, Kim JM. (2001) Purification and properties of extracellular phytase from Bacillus sp. KHU-10. J Prot Chem. 2001; 20: 287-292.

Chu HM, Guo RT, Lin TW, Chou CW, Shr HL, Lai HL, et al. Structures of Selenomonas ruminantium phytase in complex with persulfated phytate: DSP phytase fold and mechanism for sequential substrate hydrolysis. Structure 2004; 12: 2015-2024.

Damiani G, Amedeo P, Bandi C, Fani R, Bellizi D, Sgamarella V. Bacteria identification by PCR-based techniques. In: Adolph KW. Microbial genome methods. Florida: CRC Press, 1996, 167p.

Demirkan E, Baygin E, Ustaet A. Screening of phytate hydrolysis Bacillus sp. isolated from soil and optimization of the certain nutritional and physical parameters on the production of phytase. Turk $J$ Biochem. 2014; 39: 206-214.
El-Toukhy NMK, Youssef AS, Mikhail MGM. Isolation, purification and characterization of phytase from Bacillus subtilis MJA. Afr J Biotechnol. 2013; 12: 2957-2967.

Greiner R, Konietzny U. Phytase for food application. Food Technol Biotechnol. 2006; 44: 125-140.

Gulati HK, Chadha BS, Saini HS. Production and characterization of thermostable alkaline phytase from Bacillus laevolacticus isolated from rhizosphere soil. J Ind Microbiol Biotechnol. 2007; 34: 91-98.

Ha NC, Oh BC, Shin S, Kim HJ, Oh TK, Kim YO, et al. Crystal structures of a novel, thermostable phytase in partially and fully calcium-loaded state. Nat Struc Biol. 2000; 7: 147-153.

Heinonen JK, Lahti RJ. A new and convenient colorimetric determination of inorganic orthophosphate and its application to the assay of inorganic pyrophosphatase. Anal Biochem. 1981; 113: 313-317.

Iqbal TH, Lewis KO, Cooper BT. Phytase activity in the human and rat small intestine. Gut 1994; 35: 1233-1236.

Jain U, Chauhan N. Bacillus cereus 10072 Phytase Detection, purification, characterization and physiological role. Int J Sci Res Develop. 2014; 2: 1419.

Jorquera MA, Hernandes MT, Rengel Z, Marschner P, and Mora MDL. Isolation of culturable phosphobacteria with both phytase-mineralization and phosphate-solubilization activity from rhizosphere of plant grown in a volcanic soil. Biol Fertil Soils. 2008; 44: 1025-1034.

Joseph I, Raj RP. (2007) Isolation and characterization of phytase producing Bacillus strains from mangrove ecosystem. J Mar Biol Assoc India. 2007; 49: 177182.

Kembhavi A. Biotechnology application for the Indian animal food industry: Prospect for Growth. [Internet]. 2005 [cited $2015 \quad$ Mar 19] http://www.fao.org/docrep/ARTICLE/AGRIPPA/660 _en00.htm\#TopOfPage.

Kerovuo J, Lauraeus M, Nurminen P, Kalkkinen N, and Apajalahti J. (1998) Isolation, characterization, molecular gene cloning, and sequencing of a novel phytase from Bacillus subtilis. App Environ Microbiol: 1998, 64: 2079-2085.

Kim YO, Kim HK, Bae KS, Yu JH; Oh TK. Purification and properties of a thermostable phytase from Bacillus sp. DS11. Enzyme Microbial Technol. 1998; 22: 2-7.

Konietzny U, Greiner R. Molecular and catalytic properties of phytate-degrading enzymes (phytases). Int J Food Sci Technol. 2002, 37: 791-812.

Kumar D, Rajesh S, Balashanmugam P, Rebecca LJ, Kalaichelvan PT. Screening, optimization and application of extracellular phytase from Bacillus megaterium isolated from poultry waste. J Mod Biotechnol. 2013, 2: 46-52. 
Mitchell DB, Vogel K, Weimann BJ, Pasamontes L, van Loon APGM. The phytase subfamily of histidine acid phosphatases: Isolation of genes for two novel phytases from the fungi Aspergillus terreus and Myceliophthora thermophile. Microbiol. 1997; 143: 245-252.

Oh BC, Kim MH, Yun BS, Choi WC, Park SC, Bae SC, et al. $\mathrm{Ca}^{2+}$-inositol phosphate chelation mediates the substrate specificity of $\beta$-propeller phytase. Biochemistry 2006; 45: 9531-9539.

Park YJ. (2001) Expression, characterization, and antifungal activity of phytase from Bacillus subtilis TS16-111 [PhD Thesis]. Seoul, South Korea: Seoul National University.

Powar VK, Jagannathan V. Purification and properties of phytate-specific phosphatase from Bacillus subtilis. J Bacteriol. 1982; 151: 1102-1108.

Shamna KS, Rajamanikandan KCP, Mukesh Kumar DJ, Balakumaran MD, Kalaichelvan PT. Extracellular production of phytases by a native Bacillus subtilis strain. Ann Biol Res. 2012; 3: 979-987.

Shimizu M Purification and characterization of a phytase from Bacillus subtilis (natto) N-77. Biosci Biotech Biochem. 1992, 56: 1266-1269.

Shin S, Ha NC, Oh BC, Oh TK, Oh BH. Enzyme mechanism and catalytic property of beta propeller phytase. Structure 2001; 9: 851-858.
Shivange AV, Serwe A, Dennig A, Roccatano D, Haefner S, Schwaneberg U. Directed evolution of a highly active Yersinia mollaretii phytase. App Microbiol Biotechnol. 2012; 95: 405-418.

Singh NK, Joshi DK, Gupta RK. Isolation of phytase producing bacteria and optimization of phytase production parameters. J J Microbiol. 2013, 6: e6419.

Tye AJ, Siu FK, Leung TY, Lim BL. Molecular cloning and the biochemical characterization of two novel phytases from B. subtilis 168 and B. licheniformis. App Microbiol Biotechnol. 2002, 59, 190-197.

Ushasri K, Sivaragini P, Vijayalakshmi K. Isolation, characterization of phytase producing Bacillus sps NBtRS6 from the rhizospere soil of NBt cotton field. International. J Cur Microbiol Appl Sci. 2013, 2: 142-149.

Weaver CM, Kannan S. Phytate and mineral bioavailability. In: Reddy NR, Sathe SK. Food Phytates. London: CRC Press, 2001, 211p.

$\mathrm{Yu}$ P, Chen Y. Purification and characterization of a novel neutral and heat-tolerant phytase from a newly isolated strain Bacillus nealsonii ZJ0702. BMC Biotechnol. 2013; 13: 78-85.

Received: April 19, 2015; Accepted: June 16, 2015. 